\title{
Original article (Orijinal araştırma) \\ Determination of the efficacy of some entomopathogenic nematodes against Tuta absoluta (Meyrick) (Lepidoptera: Gelechiidae) under laboratory conditions ${ }^{1}$
}

\author{
Bazı entomopatojen nematodların Tuta absoluta (Meyrick) (Lepidoptera: \\ Gelechiidae)'ya karşı etkilerinin laboratuvar koşullarında belirlenmesi \\ Sevgi TÜRKÖZ ${ }^{2} \quad$ Galip KAŞKAVALCI ${ }^{2 \star}$
}

\begin{abstract}
Summary
The tomato leafminer, Tuta absoluta (Meyrick) (Lepidoptera: Gelechiidae) which was first detected in Izmir Province, Turkey in $\mathbf{2 0 0 9}$ has spread quickly and has become the major pest in tomato producing areas. The efficacy of three different entomopathogenic nematode (EPN) species isolates (from e-nema ${ }^{\circledR} \mathrm{GmbH}$ Schwentinental, Germany), Heterorhabditis bacteriophora (Poinar), Steinernema carpocapsae (Weiser) and Steinernema feltiae (Filipjev) was investigated against $T$. absoluta during 2013-2014 under laboratory conditions. The EPNs were applied with different inoculation rates (1, 2, 5, 10, 15, 20,25 and 40 infective juveniles per larva) for each species to the third instar larvae of $T$. absoluta outside the leaves. The mortality rates for $H$. bacteriophora, S. carpocapsae and S. feltiae were found between 21.2 - 74.2\%, 28.8 - 99.4\% and 17.5 $95.2 \%$, respectively. According to the results, S. carpocapsae and S. feltiae caused similar mortalities at the given inoculation rates while $H$. bacteriophora had lower efficacy compared to those two species. The values of $\mathrm{LD}_{50}$ for $H$. bacteriophora, $S$. carpocapsae and $S$. feltiae were 21.67, 7.13 and 6.25 infective juveniles per larva, respectively. Based on these data, $S$. feltiae was the most efficient nematode species, and was then applied against the larva of $T$. absoluta inside the mines and pupae. However, S. feltiae only caused low mortality of larvae both inside mines (19\%) and the pupae $(7 \%)$. These results revealed that EPN have good potential for the control of $T$. absoluta larvae outside the leaves and should be studied further.
\end{abstract}

Key words: Efficacy, Heterorhabditis, Steinernema, tomato, Tuta absoluta

\section{Özet}

Türkiye'de ilk defa 2009 yılında İzmir ilinde tespit edilen domates güvesi, Tuta absoluta (Meyrick) (Lepidoptera: Gelechiidae) hızı bir şekilde yayılarak domates üretim alanlarında ana zararlı konumuna gelmiştir. Üç farklı entomopatojen nematod (EPN) türü olan, Heterorhabditis bacteriophora (Poinar), Steinernema carpocapsae (Weiser) ve Steinernema feltiae (Filipjev) izolatları(e-nema ${ }^{\circledR} \mathrm{GmbH}$ Schwentinental, Almanya)'nın Tuta absoluta'ya karşı olan etkiler 2013-2014 yılları arasında Ege Üniversitesi, Ziraat Fakültesi, Bitki Koruma Bölümü, Nematoloji Laboratuvarı'nda laboratuvar koşulları altında araştırımışı̦ır. EPN'lerin her bir türü, yaprak dışında bulunan üçüncü dönem $T$. absoluta larvalarına farkı inokulasyon oranlarında $(1,2,5,10,15,20,25,40$ IJ/larva) uygulanmıştır. Ölüm oranları Heterorhabditis bacteriophora, $S$. carpocapsae ve $S$. feltiae için sırasıyla \%21.2-74.2, \%28.8-99.4 ve \%17.5-95.2 olarak bulunmuştur. Elde edilen sonuçlara göre, $S$. carpocapsae ve $S$. feltiae belirlenen inokulasyon oranlarında benzer ölüm oranlarına sebep olurken, $H$. bacteriophora' nın bu iki türe kıyasla daha düşük düzeyde etkiye sahip olduğu görülmüştür. $H$. bacteriophora, S. carpocapsae ve $S$. feltiae için $L D_{50}$ değerleri sırasıyla $21.67,7.13$ ve 6.25 ' dir. Bu değerlendirmelere göre en yüksek etkiye sahip nematod türü olarak saptanan $S$. feltiae' nin $\mathrm{LD}_{50}$ dozu yaprak içerisinde bulunan $T$. absoluta larvalarına ve pupa dönemlerine uygulanmıştır. Ancak S. feltiae yaprak içerisindeki larvalarda $(\% 19)$ ve pupalarda $(\% 7)$ düşük miktarda ölüme yol açmışıı. Bu sonuçlar, EPN'ların yaprak dışında bulunan T. absoluta larvalarııın mücadelesinde iyi bir potansiyel olabileceğini ve ileride daha detaylı bir şekilde araştırıması gerektiğini ortaya koymuştur.

Anahtar sözcükler: Etkinlik, Heterorhabditis, Steinernema, domates, Tuta absoluta

\footnotetext{
1 This study is a part of Master Science thesis of the first author, accepted at 07.10.2015 in E.U. Graduate School of Natural and Applied Sciences. This study was undertaken as a part of research project supported by Ege University Scientific Research Commission (Project number: 2011-ZRF-043).

2 Ege University, Agricultural Faculty, Plant Protection Department, 35100, Bornova, İzmir-Türkiye

* Corresponding author (Sorumlu yazar) e-mail: galip.kaskavalci@ege.edu.tr

Received (Alınış):14.03.2016 Accepted (Kabul ediliş): 01.06.2016 


\section{Introduction}

In Turkey, about $46.7 \mathrm{Mt}$ of fresh vegetables and fruit are produced each year of which $28.5 \mathrm{Mt}$ is vegetables. Tomato is one of the most widely grown vegetable with the production capacity of $11.8 \mathrm{Mt}$ (Anonymous, 2016). There are many diseases and pest that can economically affect tomatoes. Among these, the tomato leaf miner [Tuta absoluta (Meyrick) (Lepidoptera: Gelechiidae)] is one of the most economically harmful. This pest originates from South America and was first seen in Europe in Spain in 2006 (Urbaneja et al., 2007), later on in France, Italy, Malta, the Netherlands, England, Hungary, Bulgaria and in the North African countries, Algeria, Morocco and Tunisia (Potting, 2009). It was then detected in West Africa in 2010 (USDA-APHIS, 2011), Sudan and Ethiopia in 2011 (Anonymous, 2013) and crossed the Sahara Dessert in West Africa and reached to Senegal in 2013 (Pfeiffer et al., 2013; Brévault et al., 2014). In Turkey, it was first detected in Urla District, İzmir Province, in 2009 (Kılıc, 2010). It has since spread quickly in Mediterranean Basin as well as the other regions. In Mediterranean Region, it has been caught in pheromone traps of a producer in Kumluca District, Antalya Province (Erler et al., 2010).

Tuta absoluta has high potential for reproduction and with 12 generations per year. Although its primary host is tomato, it can also feed on secondary host from the Solanaceae. One female can lay approximately 120 to 260 eggs. The pest generally lays its eggs under leaves, on buds or on immature fruit. The larvae are able to feed on the entire plant above the soil, leaves, stalks, stems and fruit. It feeds between the epidermis of the leaves by tunnelling irregular galleries. These galleries may become a brownish color and the whole plants may die (Desneux et al., 2010).

The control of tomato leaf miner is difficult because the pest feeds inside the mines, develop resistance to insecticides and reproduce quickly. Since chemical control is not sufficient alone, the damage (if it is not controlled) may increase to 80 to $100 \%$ in open field and greenhouse tomato production. There is a pressing need to develop sustainable control methods against this pest. In this context, biological control has a significant role because it is safe for the environment and non-target organisms, decreases residue problems in food, protects natural enemies and increases biological diversity in ecosystems. Thus, the entomopathogenic nematodes (EPN) are efficient biological control agents for many pests that are economically important (Grewal et al., 2005).

EPNs, Steinernema and Heterorhabditis, have infective juvenile (IJ) stages like the other orders of Rhabditida. The IJs are adapted to long term survival and contains between 0-250 symbionts in the anterior region of their intestine (Spiridonov et al., 1991; Glazer, 1996). The EPNs belonging to the family of Steinernematidae and Heterorhabditidae are obligate parasites of many pathogens. They can kill pests with their symbiotic bacteria (Photorhabdus sp. and Xenorhabdus sp.), which live in their intestine. Nonfeeding third stage IJs penetrate through natural openings (mouth, anus and stigma), or in some species (Heterorhabditis spp.) through the cuticle, and enter the hemocoel of the host releasing their symbiotic bacteria into the haemolymph of their host. These bacteria propagate and produce toxins (Dowds \& Peters, 2002) and other metabolites (Webster et al., 2002) to suppress the defense mechanisms of the host, which usually dies within $48 \mathrm{~h}$ of invasion by the nematode. The cadaver provides food for the nematode for up to three generations (Poinar, 1990; Kaya \& Gaugler, 1993). When the nematodes leave the insect cadaver, they seek a new host.

EPNs are safe biological control agents and have been successfully used against soilborne insects in ornamental plants, turf, mushrooms and strawberries (Ehlers, 1996; Kaya \& Gaugler, 1993), and also against pest with cryptic habitats where the pests are highly protected inside galleries of plants (Begley, 1990; Klein, 1990; Williams \& Walters, 1999; Tomalak et al., 2005). 
There have been some studies conducted to examine the efficacy of EPN on $T$. absoluta. BatallaCarrera et al. (2010) recorded high mortality (78.6 - 100\%) of $T$. absoluta larvae when EPN were applied under laboratory conditions. In addition, they have observed $87-95 \%$ decrease in the infestation of tomato leaves in a pot experiment. Garcia-del Pino et al. (2013) also found high mortality of $T$. absoluta larvae that fall down to pupate in the soil. The mortality rate of $T$. absoluta larvae caused by Heterorhabditis bacteriophora (Poinar), Steinernema carpocapsae (Weiser) and Steinernema feltiae (Filipjev) was 97, 100 and 52\%, respectively. They have also reported the mortality of emerging adults as to be $79 \%$ for S. carpocapsae and $0.5 \%$ for S. feltiae. In another study conducted in Turkey by Gözel et al. (2014), the efficacy of EPNs both in the laboratory and under natural conditions was evaluated at different temperatures. Different results were observed in the two contexts. In another study done in the same region by Gözel \& Kasap (2015), S. feltiae was found to be the most efficient nematode in an open field application over two growing seasons.

EPNs are seen as suitable candidates for sustainable agriculture and integrated pest management owing to their behaviour. They have many advantages such as, wide host range, rapid host death, actively seek and invade their hosts, easily cultured in vivo and in vitro, suitable for standard application equipment, safe for the environment, and exempted from registration in many countries (Shapiro-llan et al., 2012).

The aim of this work was to evaluate the use of EPNs against Tuta absoluta, which has recently caused serious losses in tomato production and has become a major tomato pest.

\section{Materials and Methods}

\section{Host plant culture}

Tomato seedlings (cv. Şimşek) were planted with sterilized peat mixture into the pots every 2 months in a greenhouse at the Plant Protection Department, Ege University. Fertilizer was applied regularly from $15 \mathrm{~d}$ after planting.

\section{Tuta absoluta culture}

The initial population of $T$. absoluta was obtained as culture from Akdeniz University, Plant Protection Department. To culture T. absoluta, fresh tomato branches were cut and put in a jar filled with water and placed in $0.5 \times 1 \times 0.5 \mathrm{~m}$ cages. Adults of tomato leaf miner were then put into these cages to deposit eggs. The eggs hatched after 5 days and started feeding within galleries. To maintain the culture, the plants were checked and replaced with fresh branches once per week.

\section{Galleria mellonella L. (Lepidoptera: Pyralidae) culture}

In vivo EPN cultures were established using the final instar larvae of wax moth Galleria mellonella L. (Lepidoptera: Pyralidae). Galleria mellonella larvae were reared on artificial medium (22\% corn groats, $22 \%$ wheat flour, $11 \%$ honey, $11 \%$ glycerol, $5.5 \%$ yeast powder and $17.5 \%$ beeswax) inside a glass jar at $35^{\circ} \mathrm{C}$ under laboratory conditions. The adults and larvae of $G$. mellonella were kept separately. Tissue paper is placed on top of the jar for adult to lay eggs. The eggs were collected and placed in fresh medium to maintain the culture.

\section{Entomopathogenic nematode culture}

The EPNs ( $H$. bacteriophora, $S$. carpocapsae and $S$. feltiae) used in this study were obtained from e-nema ${ }^{\circledR} \mathrm{GmbH}$ (Schwentinental, Germany). They were propagated in vivo using the final instar larvae of G. mellonella as described by Kaya \& Stock (1997). Different batches of G. mellonella larvae were inoculated with 80 to $100 \mathrm{IJ} /$ larva and kept in the dark at $25^{\circ} \mathrm{C}$. Three to $4 \mathrm{~d}$ after inoculation, dead cadavers of $G$. mellonella larvae were transferred to White traps in order to allow the emergence of IJs. Freshly emerged IJs were collected from the White traps and stored in Ringer's solution $(9.0 \mathrm{~g} \mathrm{NaCl}$, $0.42 \mathrm{~g} \mathrm{KCl}, 0.37 \mathrm{~g} \mathrm{CaCl}_{2} .2 \mathrm{H}_{2} \mathrm{O}$ and $0.2 \mathrm{~g} \mathrm{NaHCO}_{3}$, in 1 I distilled water) until used. 


\section{Application of entomopathogenic nematodes}

The EPNs were applied to third instar larvae of $T$. absoluta outside the leaves, final instar larvae inside the mines and to pupae at different inoculation rates. The experiment was included 20 replications at three application times (totally 60 larvae) for each species of nematodes. For each group 20 larvae were used as a control group.

For the application of nematodes to the third instar larvae of $T$. absoluta outside the leaves, moistened filter paper and the tomato leaf disks were placed into 24-well plates, then each larvae was transferred individually into a well. Nematodes were checked for viability before use. Nematodes were applied at 1, 2, 5, 10, 15, 20, 25 and $40 \mathrm{IJ}$ per tomato leaf miner larvae for each species. Water was applied to the control larvae. Plates were wrapped with Parafilm and stored at $25^{\circ} \mathrm{C}$.

For the application of nematodes to $T$. absoluta inside the mines, leaf disks with one larva were placed in each well of 24 -well plates with tissue paper on the bottom. The $\mathrm{LD}_{50}$ inoculation rate for $S$. feltiae, the most efficient nematode strain from the previous experiment, was used for the larvae inside the mines. The plates were covered and stored at $25^{\circ} \mathrm{C}$.

For the pupa experiment, $T$. absoluta pupae were placed into the 24-well plates and each well filled with $10 \%$ moistened sterilized sand. The $\mathrm{LD}_{50}$ inoculation rate for $S$. feltiae was applied to each well. The plates were wrapped with Parafilm and stored in dark.

\section{Statistical analysis}

All data was evaluated using SPSS (Version 15.00; SPSS, Chicago, IL, USA) statistical software. The mean mortality was compared with ANOVA and groups were determined with Duncan's test. The data obtained from the efficacy of EPN on $T$. absoluta outside the leaves was corrected with Abbots formula (Abbott, 1925) and the data was square root transformed before analysis. To evaluate the $L_{50}$ probit analyses was performed with BioStat 2009 (AnalystSoft Inc., Vancouver, Canada).

\section{Results and Discussions}

This study demonstrated the efficacy of three different species of EPNs ( $H$. bacteriophora, $S$. carpocapsae and $S$. feltiae) with 8 different inoculation rates ranging between 1 and $40 \mathrm{IJ} /$ larva on $T$. absoluta larvae outside the leaves. The data obtained from this experiment were evaluated in two ways; the efficacy of each EPN species and a comparison of the efficacy of three different species at the same inoculation rates. Afterwards, $\mathrm{LD}_{50}$ values of three different nematode species were calculated and the most effective species, $S$. feltiae, was applied to $T$. absoluta larvae inside mines and to pupae to assess the efficacy this nematode.

The efficacy of entomopathogenic nematodes on Tuta absoluta outside the leaves for each nematode species

For S. feltiae, the mortality was ranged between 17.5 and $95.2 \%$. The highest mortality was obtained at $40 \mathrm{IJ} /$ larva. Significant differences were recorded between the inoculation rates of 1,2 and $5 \mathrm{IJ} /$ larva $(\mathrm{F}=36.0$; $\mathrm{df}=7 ; \mathrm{P} \leq 0.05)$ (Table 1). However there were no significant differences at inoculation rates of $15,20,25$ and $40 \mathrm{IJ} /$ larva.

For S. carpocapsae, the mortality was ranged between 28.8 and $99.4 \%$. The highest mortality was obtained at $40 \mathrm{IJ} /$ larva. However, there were no significant differences in the mortality at $40 \mathrm{IJ} / \mathrm{larva}$ between the inoculation rates of 20 and $25 \mathrm{IJ} /$ larva. Significant differences were observed at 5 and $10 \mathrm{IJ} /$ larva $(\mathrm{F}=34.5 ; \mathrm{df}=7 ; \mathrm{P} \leq 0.05)$ (Table 1). 
For $H$. bacteriophora, the mortality was ranged between 21.2 and $74.2 \%$. The highest mortality was reached at $40 \mathrm{IJ} /$ larva. However this was not significantly different from 20 and $25 \mathrm{IJ} / \mathrm{larva}$. Also, no significant differences was observed at 1,2 and $5 \mathrm{IJ} / \mathrm{larva}(\mathrm{F}=12.0 ; \mathrm{df}=7 ; \mathrm{P} \leq 0.05)$ (Table 1$)$.

Table 1. Mortality of Tuta absoluta (Meyrick) (Lepidoptera: Gelechiidae) larvae outside the leaves caused by three different entomopathogenic nematode species [(mean $\pm S D)(\min , \max )],(n=60)$

\begin{tabular}{|c|c|c|c|c|c|c|}
\hline \multirow{2}{*}{$\begin{array}{l}\text { Inoculation } \\
\text { rates }\end{array}$} & \multicolumn{2}{|c|}{ Heterorhabditis bacteriophora } & \multicolumn{2}{|c|}{ Steinernema carpocapsae } & \multicolumn{2}{|c|}{ Steinernema feltiae } \\
\hline & \multicolumn{2}{|c|}{ Mortality (\%) } & \multicolumn{2}{|l|}{ Mortality (\%) } & \multicolumn{2}{|l|}{ Mortality (\%) } \\
\hline 1 & $\begin{array}{c}21.21 \pm 1.52 \\
(18.18-22.73)\end{array}$ & $a^{*}$ & $\begin{array}{c}28.79 \pm 4.01 \\
(22.73-36.36)\end{array}$ & $\mathrm{a}$ & $\begin{array}{c}17.46 \pm 1.59 \\
(14.29-19.05)\end{array}$ & $a^{*}$ \\
\hline 2 & $\begin{array}{c}25.76 \pm 1.52 \\
(22.73-27.27)\end{array}$ & $a b$ & $\begin{array}{c}36.36 \pm 2.62 \\
(31.82-40.91)\end{array}$ & $a b$ & $\begin{array}{c}30.16 \pm 3.17 \\
(23.81-33.33)\end{array}$ & $\mathrm{b}$ \\
\hline 5 & $\begin{array}{c}31.82 \pm 5.25 \\
(22.73-40.91)\end{array}$ & $a b c$ & $\begin{array}{c}45.45 \pm 7.87 \\
(31.82-59.09)\end{array}$ & $\mathrm{b}$ & $\begin{array}{c}69.84 \pm 8.84 \\
(52.38-80.95)\end{array}$ & $\mathrm{C}$ \\
\hline 10 & $\begin{array}{c}39.39 \pm 8.02 \\
(27.27-54.55)\end{array}$ & bc & $\begin{array}{c}69.70 \pm 6.06 \\
(63.64-81.82)\end{array}$ & c & $\begin{array}{c}62.11 \pm 8.07 \\
(48.24-76.19)\end{array}$ & $\mathrm{cd}$ \\
\hline 15 & $\begin{array}{c}42.42 \pm 1.51 \\
(40.91-45.45)\end{array}$ & $\mathrm{cd}$ & $\begin{array}{c}83.33 \pm 8.02 \\
(68.18-95.45)\end{array}$ & $\mathrm{cd}$ & $\begin{array}{c}77.78 \pm 1.59 \\
(76.19-80.95)\end{array}$ & de \\
\hline 20 & $\begin{array}{c}59.09 \pm 9.46 \\
(45.45-77.27)\end{array}$ & de & $\begin{array}{c}93.94 \pm 1.51 \\
(90.91-95.45)\end{array}$ & $d$ & $\begin{array}{c}82.54 \pm 1.59 \\
(80.95-85.71)\end{array}$ & de \\
\hline 25 & $\begin{array}{c}65.15 \pm 1.51 \\
(63.64-68.18)\end{array}$ & $\mathrm{e}$ & $\begin{array}{c}95.45 \pm 0.00 \\
(95.45-95.45)\end{array}$ & $d$ & $\begin{array}{c}90.48 \pm 2.75 \\
(85.71-95.24)\end{array}$ & $\mathrm{e}$ \\
\hline 40 & $\begin{array}{c}74.24 \pm 7.58 \\
(59.09-81.82)\end{array}$ & e & $\begin{array}{c}99.39 \pm 0.61 \\
(98.18-100.00)\end{array}$ & $d$ & $\begin{array}{c}95.24 \pm 2.75 \\
(90.48-100.00)\end{array}$ & $\mathrm{e}$ \\
\hline
\end{tabular}

*The mortalities include the same letter are not statistically different from each other using Duncan's test $(P \leq 0.05)$.

In a study conducted by Gözel \& Kasap (2015), the susceptibility of EPN to T. absoluta larvae was also recorded as high for all EPN species used. However the level of susceptibility differed depending on the nematode species. They conducted their experiments in an open field during two successive years. In both years, S. feltiae (isolate 879 ) was recorded as the most efficient with 90.7 and $94.3 \%$ mortality rate in the first and second year, respectively. The least efficient species was Steinernema affine (Bovien) (isolate 46) in both years with 39.3 and $43.7 \%$ mortality. In another study conducted by Gözel et al. (2014), the efficacy of EPNs both in laboratory and natural conditions was evaluated at different temperatures. They have observed 0 to $87.5 \%$ mortality for $\mathrm{H}$. bacteriophora, 8.3 to $83.3 \%$ for $S$. affine, 12.5 to $87.5 \%$ for $S$. carpocapsae and 8.3 to $91.6 \%$ for $S$. feltiae in laboratory assays. Whereas, under natural conditions they have found 0 to $85.5 \%$ mortality for $H$. bacteriophora, 0 to $41.2 \%$ for $S$. affine, 0 to $47.4 \%$ for S. carpocapsae and 0 to $95.6 \%$ for $S$. feltiae.

\section{The efficacy of entomopathogenic nematodes on Tuta absoluta outside the leaves at different inoculation rates}

The mortality of $T$. absoluta for each inoculation rate were evaluated separately to compare the differences for each nematode species.

At $1 \mathrm{IJ} /$ larva, the highest mortality was $28.8 \%$ for $S$. carpocapsae. The mortality rate difference between $S$. feltiae and $S$. carpocapsae was significant. However, no significant differences were found for S. carpocapsae $(28.8 \%)$ and $H$. bacteriophora $(21.2 \%)(F=4.78 ; \mathrm{df}=2 ; \mathrm{P} \leq 0.05)($ Table 2). 
At $2 \mathrm{IJ} /$ larva, $S$. carpocapsae caused the highest mortality of $36.4 \%$, while the $H$. bacteriophora caused the lowest mortality $(25.8 \%)$ and the difference between these two species was significant. No difference was found between the Steinernema spp. ( $F=4.43$; $\mathrm{df}=2 ; \mathrm{P} \leq 0.05)$ (Table 2).

At $5 \mathrm{IJ} /$ larva, $S$. feltiae was the most efficient nematode with a mortality rate of $69.8 \%$. The least efficient nematode was found as $H$. bacteriophora with $31.8 \%$ mortality and the differences between $S$. feltiae and $H$. bacteriophora was found significant $(F=6.64 ; \mathrm{df}=2 ; \mathrm{P} \leq 0.05)$ (Table 2).

Table 2. Mortality of Tuta absoluta (Meyrick) (Lepidoptera: Gelechiidae) larvae outside the leaves at each inoculation rates $[($ mean $\pm S D),(\min , \max )],(\mathrm{n}=60)$

\begin{tabular}{|c|c|c|c|c|}
\hline \multirow{2}{*}{$\begin{array}{l}\text { Inoculation } \\
\text { rates }\end{array}$} & \multirow{2}{*}{$\begin{array}{l}\text { Nematode species } \\
\text { Heterorhabditis bacteriophora }\end{array}$} & \multicolumn{3}{|c|}{ Mortality (\%) } \\
\hline & & $21.21 \pm 1.52$ & $(18.18-22.73)$ & $a b^{*}$ \\
\hline \multirow[t]{3}{*}{1} & Steinernema carpocapsae & $28.79 \pm 4.00$ & $(22.73-36.36)$ & $\mathrm{b}$ \\
\hline & Steinernema feltiae & $17.46 \pm 1.59$ & $(14.29-19.05)$ & a \\
\hline & Heterorhabditis bacteriophora & $25.76 \pm 1.51$ & $(22.73-27.27)$ & a \\
\hline \multirow[t]{3}{*}{2} & Steinernema carpocapsae & $36.36 \pm 2.63$ & $(31.82-40.91)$ & $\mathrm{b}$ \\
\hline & Steinernema feltiae & $30.16 \pm 3.17$ & $(23.81-33.33)$ & $a b$ \\
\hline & Heterorhabditis bacteriophora & $31.82 \pm 5.25$ & $(22.73-40.91)$ & a \\
\hline \multirow[t]{3}{*}{5} & Steinernema carpocapsae & $45.45 \pm 7.87$ & $(31.82-59.09)$ & $a b$ \\
\hline & Steinernema feltiae & $69.84 \pm 8.84$ & $(52.38-80.95)$ & $\mathrm{b}$ \\
\hline & Heterorhabditis bacteriophora & $39.39 \pm 8.02$ & $(27.27-54.55)$ & a \\
\hline \multirow[t]{3}{*}{10} & Steinernema carpocapsae & $69.70 \pm 6.06$ & $(63.64-81.82)$ & $\mathrm{b}$ \\
\hline & Steinernema feltiae & $62.11 \pm 8.07$ & $(48.24-76.19)$ & $a b$ \\
\hline & Heterorhabditis bacteriophora & $42.42 \pm 1.51$ & $(40.91-45.45)$ & a \\
\hline \multirow[t]{3}{*}{15} & Steinernema carpocapsae & $83.33 \pm 8.02$ & $(68.18-95.45)$ & $\mathrm{b}$ \\
\hline & Steinernema feltiae & $77.78 \pm 1.59$ & $(76.19-80.95)$ & $\mathrm{b}$ \\
\hline & Heterorhabditis bacteriophora & $59.09 \pm 9.46$ & $(45.45-77.27)$ & a \\
\hline \multirow[t]{3}{*}{20} & Steinernema carpocapsae & $93.94 \pm 1.51$ & $(90.91-95.45)$ & $\mathrm{b}$ \\
\hline & Steinernema feltiae & $82.54 \pm 1.59$ & $(80.95-85.71)$ & $\mathrm{b}$ \\
\hline & Heterorhabditis bacteriophora & $65.15 \pm 1.51$ & $(63.64-68.18)$ & a \\
\hline \multirow[t]{3}{*}{25} & Steinernema carpocapsae & $95.45 \pm 0.00$ & $(95.45-95.45)$ & $\mathrm{b}$ \\
\hline & Steinernema feltiae & $90.48 \pm 2.75$ & $(85.71-95.24)$ & $\mathrm{b}$ \\
\hline & Heterorhabditis bacteriophora & $74.24 \pm 7.58$ & $(59.09-81.82)$ & a \\
\hline \multirow[t]{2}{*}{40} & Steinernema carpocapsae & $99.39 \pm 0.61$ & $(98.18-100.0)$ & $\mathrm{b}$ \\
\hline & Steinernema feltiae & $95.24 \pm 2.75$ & $(90.48-100.0)$ & $\mathrm{b}$ \\
\hline
\end{tabular}

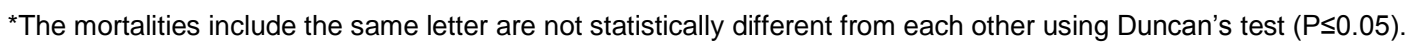

At $10 \mathrm{IJ} /$ larva the highest mortality was seen in $S$. carpocapsae with $69.7 \%$ mortality. These results were in accordance with the result of Lacey \& Unruh (1998). They studied the effect of three different nematode species ( $S$. carpocapsae, Steinernema riobrave Cabanillas, Poinar and Raulston and H. bacteriophora) at different temperatures against Cydia pomonella (L.) (Lepidoptera : Tortricidae) larvae. In their study, $S$. carpocapsae was also found to be the most efficient nematode at $10 \mathrm{~J} / \mathrm{cm}^{2}$ inoculation rate with the mortality ranging from 66 to $90 \%$.

When the three different species of EPN $(H$. bacteriophora, $S$. carpocapsae and $S$. feltiae) were compared for the remaining inoculation rates, Steinernema spp. was found to be more efficient than $H$. bacteriophora. The mortality rates for both Steinernema spp. showed differences but generally these were not siginificant. Our results were similar to those of Gözel \& Güneş (2013), who investigated 
different Turkish isolates of the EPNs against Sesamia cretica Lederer (Lepidoptera: Noctuidae) and found that $S$. carpocapsae and $S$. feltiae gave the similar results at the given temperatures.

At $25 \mathrm{IJ} /$ larva in our study, the mortalities were $65.2 \%$ for $\mathrm{H}$. bacteriophora, $95.5 \%$ for $S$. carpocapsae and $90.5 \%$ for S. feltiae. At $40 \mathrm{IJ} /$ larva, the mortalties were $74.24 \%$ for $\mathrm{H}$. bacteriophora, $99.4 \%$ for S. carpocapsae and $95.2 \%$ for S. feltiae. Our results were similar to those reported by BatallaCarrera et al. (2010). They observed the efficacy of three EPN species against $T$. absoluta and found the mortalities at $25 \mathrm{IJ} / \mathrm{cm}^{2} 78.6 \%$ for $\mathrm{H}$. bacteriophora $85.7 \%$ S. carpocapsae and $100 \%$ for $S$. feltiae, and at $50 \mathrm{IJ} / \mathrm{cm}^{2}, 100 \%$ for $H$. bacteriophora $86.6 \%$ for S. carpocapsae and $100 \%$ for S. feltiae.

\section{$\mathrm{LD}_{50}$ of nematodes}

The most efficient species for $T$. absoluta was $S$. feltiae $\left(\mathrm{LD}_{50}=6.2 \mathrm{IJ} / \mathrm{larva}\right)$ followed by $S$. carpocapsae $\left(\mathrm{LD}_{50}=7.1 \mathrm{IJ} /\right.$ larva). The least efficient species was $\mathrm{H}$. bacteriophora $\left(\mathrm{LD}_{50}=21.7 \mathrm{IJ} / \mathrm{larva}\right)$. In this study $S$. carpocapsae was more efficient than $H$. bacteriophora. Similar results were reported by Salari et al. (2014). They reported that $S$. carpocapsae $\left(\operatorname{LD}_{50}=6.4 \mathrm{IJ} /\right.$ larva) was more effective than $H$. bacteriophora $\left(\mathrm{LD}_{50}=8.4 \mathrm{IJ} /\right.$ larva) against the larvae of Zeuzera pyrina (L.) (Lepidoptera: Cossidae). Lacey \& Unruh (1998) also concluded that $S$. carpocapsae $\left(\mathrm{LD}_{50}=4.7 \mathrm{IJ} / \mathrm{larva}\right)$ was more efficient than $H$. bacteriophora $\left(\mathrm{LD}_{50}=6 \mathrm{IJ} / \mathrm{larva}\right)$.

\section{The efficacy of entomopathogenic nematodes on $T$. absoluta larvae inside the mines and pupae}

The most efficient nematode strain, $S$. feltiae, was applied with $\mathrm{LD}_{50}$ inoculation rates to the larvae of $T$. absoluta inside the mines and pupae stages. The nematodes caused $19 \%$ mortality for the larvae inside the mines. Although previous studies had shown that EPNs can be used successfully for soil dwelling Coleopteran species, there are limited studies for Lepidopteran species that are above ground pest (Klein, 1990). In our study, the mortality of tomato leaf miner larvae was quite low. Arthurs et al. (2004) showed that application on leaves for above ground pest had low efficacy. The major reason for the limited the success of the application on leaves is likely to be desiccation of IJs. Addition of an antidesiccant may help to increase the efficacy on leaves.

The most efficient nematode strain $S$. feltiae was applied at the $L_{50}$ inoculation rate to the pupae of $T$. absoluta. This resulted in $7 \%$ mortality. The mortality rate for pupae was lower than for to larval stages outside the mines. This result is in agreement with Batalla-Carrera et al. (2010), who also observed lower than $10 \%$ mortality for pupae of $T$. absoluta. Similar results were obtained by Garcia-del Pino et al. (2013), who observed no mortality in pupal stages of tomato leaf miner.

The results of this study demonstrated that EPNs could be a good candidates for the control of $T$. absoluta larval stages outside the mines, and further study of their efficacy under natural conditions is warranted.

\section{Acknowledgements}

We wish to express our gratitude to Prof. Dr. Ralf-Udo EHLERS from e-nema ${ }^{\circledR} \mathrm{GmbH}$ Schwentinental, Germany for his valuable contribution and supplying the entomopathogenic materials used in this study.

\section{References}

Abbott, W. S. 1925. A method of computing the effectiveness of an insecticide. Journal Economic Entomology, 18: 265-267.

Anonymous, 2013. Tuta absoluta Information Network. (Web page:http://www.tutaabsoluta.com), (Date accessed: December 2013). 
Anonymous, 2016. 'Agricultural Land by Provinces. (Web page: http://www.turkstat.gov.tr/PreTablo.do?alt_id=1001), (Date accessed: March 2016).

Arthurs, S., K. M. Heinz \& J. R. Prasifka, 2004. An analysis of using entomopathogenic nematodes against aboveground pests. Bulletin of Entomological Research, 94: 297-306.

Batalla-Carrera, L., A. Morton \& F. Garcia-del-Pino, 2010. Efficacy of entomopathogenic nematodes against the tomato leafminer Tuta absoluta in laboratory and greenhouse conditions. BioControl, 55: 523-530.

Begley, J. W., 1990. "Efficacy Against Insects in Habitats Others than Soil,215-231". In: Entomopathogenic Nematodes in Biological Control (Eds. R. Gaugler \& H. K. Kaya). CRC Press, Boca Raton, FL.

Brévault, T., S. Sylla, M. Diatte, G. Bernadas \& K. Diarra, 2014. Tuta absoluta Meyrick (Lepidoptera: Gelechiidae): A New Threat to Tomato Production in Sub-Saharan Africa. African Entomology, 22 (2): 441-444.

Desneux, N., E. Wajnberg, K. A. G. Wyckhuys, G. Burgio, S. Arpaia, C. A. Narvaez-Vasquez, J. Gonzalez-Cabrera, D.C. Ruescas, E. Tabone, J. Frandon, J. Pizzol, C. Poncet, T. Cabello \& A. Urbaneja, 2010. Biological invasion of European tomato crops by Tuta absoluta: Ecology, geographic expansion and prospects for biological control. Journal of Pest Science, 83: 197-215.

Dowds, B. C. \& A. Peters, 2002. "Virulence mechanisms, 79-98". In: Entomopathogenic Nematology (Ed. R. Gaugler). CABI Publishing, Oxon, UK.

Ehlers, R.U., 1996. Current and future use of nematodes in biocontrol: practice and commercial aspects with regard to regulatory policy issues. Biocontrol Science and Technology, 6: 303-316.

Erler, F., M. Can, M. Erdogan, A. O. Ates, \& T. Pradier, 2010. New record of Tuta absoluta (Meyrick) (Lepidoptera: Gelechiidae) on greenhouse-grown 46 tomato in southwestern Turkey (Antalya). Journal of Entomological Science, 45: 392-393.

Garcia-del-Pino, F., X. Alabern \& A. Morton, 2013. Efficacy of soil treatments of entomopathogenic nematodes against the larvae, pupae and adults of Tuta absoluta and their interaction with the insecticides used against this insect. BioControl, 58: 723-731.

Glazer, I., 1996. Survival mechanisms of entomopathogenic nematodes. Biocontrol Science and Technology, 6: $373-378$.

Gözel, U. \& Ç. Güneş, 2013. Effect of entomopathogenic nematode species on the corn stalk borer (Sesamia cretica Led. Lepidoptera: Noctuidae) at different temperatures. Türkiye Entomoloji Dergisi-Turkish Journal of Entomology, 37 (1): 65-72.

Gözel, Ç., U. Gözel \& İ. Kasap, 2014. “Domates güvesi Tuta absoluta Meyrick (Lepidoptera: Gelechiidae)'nin mücadelesinde entomopatojen nematodların kullanım olanakları, 319”. Türkiye V. Bitki Koruma Kongresi (3-5 Şubat 2014, Antalya) Bildirileri, XMAT Matbaa, 417 s.

Gözel, Ç. \& İ. Kasap, 2015. Efficacy of entomopathogenic nematodes against the Tomato leafminer, Tuta absoluta (Meyrick) (Lepidoptera: Gelechiidae) in tomato field. Türkiye Entomoloji Dergisi-Turkish Journal of Entomology, 39 (3): 229-237.

Grewal, P. S., R. U. Ehlers \& D. I. Shapiro-llan, 2005. Nematodes as Biocontrol Agents. CABI Publisher, Wallingford, UK, 505pp.

Kaya, H. K. \& R. Gaugler, 1993. Entomopathogenic nematodes. Annual Review of Entomology, 38: $181-206$.

Kaya, H. K. \& S. P. Stock, 1997. "Techniques in Insect Nematology, 281-324". In: Manual of Techniques in Insect Pathology, (Ed. L. A. Lacey). Academic Press, San Diego.

Kılıc, T., 2010. First record of Tuta absoluta in Turkey. Phytoparasitica, 38: 243-244.

Klein, M. G., 1990. "Efficacy against Soil-Inhabiting Insects Pest, 195-214". In: Entomopathogenic Nematodes Biological Control, (Eds. R. Gaugler \& H. K. Kaya). CRC Press, Boca Raton, FL.

Lacey, L. A. \& T. R. Unruh, 1998. Entomopathogenic nematodes for control of codling moth: Effect of nematode species, dosage, temperature, and humidity under laboratory and simulated field conditions. Biological Control, 13:190-197.

Pfeiffer, D. G., R. Muniappan, D. Sall, P. Diatta, A. Diongue \& E. O. Dieng, 2013. First record of Tuta absoluta (Lepidoptera: Gelechiidae) in Senegal. Florida Entomologist, 96: 661-662. 
Poinar, G. O. Jr., 1990. "Biology and taxonomy of Steinernematidae and Heterorhabditidae, 23-61". In: Entomopathogenic Nematodes in Biological Control (Eds: R., Gaugler \& H. K. Kaya). CRC Press, Boca Raton, FL.

Potting, R., 2009. Pest risk analysis. Tuta absoluta, tomato leaf miner moth. Plant Protection Service of the Netherlands, 24.

Salari, E., Karimi, J., Sadeghi-Nameghi, H. \& Hosseini, M., 2014. Efficacy of two entomopathogenic nematodes Heterorhabditis bacteriophora and Steinernema carpocapsae for control of the leopard moth borer Zeuzera pyrina (Lepidoptera: Cossidae) larvae under laboratory conditions. Biocontrol Science and Technology, 25 (3): 260-275.

Shapiro-Ilan, D. I., R. Han \& C. Dolinksi, 2012. Entomopathogenic nematode production and application technology. Journal Nematology, 44 (2): 206-217.

Spiridonov, S., E. Akhmedov \& F. Belostotskaya, 1991. Proliferation of symbiotic bacteria in the intestinal vesicles of invasive larvae of Neoaplectana spp.(Nematoda, Steinernematidae). Helminthologia, 28: 141-142.

Tomalak, M., S. Piggott \& G. B. Jagdale, 2005. "Glasshouse Applications, 147-166". In: Nematodes as Biocontrol Agents (Eds. P. S. Grewal, R. U. Ehlers \& D. I. Shapiro-llan). CABI Publishing, Oxon.

Urbaneja, A., R. Vercher, V. Navarro, F. Garcia Mari \& J. L. Porcuna, 2007. La polilla del tomate, Tuta absoluta. Phytoma España, 194:16-23.

Usda-Aphis, 2011. Federal import quarantine order for host materials of tomato leafminer, Tuta absoluta (Meyrick), (Web page: http://www.aphis.usda.gov/import_export/plants/plant_imports/federal_order/downloads/2011/Tuta\%20absolut a5-5-2011.pdf), (Date accessed: April 2014).

Webster, J. M., C. Chen \& K. Hu, 2002. Bacterial metabolites. Entomopathogenic Nematology, 99-114.

Williams, E. C. \& K. F. A. Walters, 1999. Foliar application of entomopathogenic nematode Steinernema feltiae against leafminers on vegetables. Biocontrol Science and Technology, 10: 61-70. 